Jean LEE, WEI Feng

\title{
Uncover the black-box of leadership effectiveness: Leader-member exchange as the mediator
}

\author{
(C) Higher Education Press and Springer-Verlag 2008
}

\begin{abstract}
This study is an integration of the leader-focused perspective and leader-follower exchange perspective, attempting to understand the relationship between leadership styles, leader-member relationship, and their joint impact on followers' effectiveness, satisfaction, extra effort and organizational commitment. 615 respondents from five big pharmaceutical companies in China participated in this study. Results show that: (1) transformational leadership has positive influence on followers' effectiveness, satisfaction, extra effort and organizational commitment; contingent reward has positive influence on effectiveness; management-by-exception leadership has negative influence on satisfaction; laissez-faire leadership has negative influence on effectiveness and satisfaction. (2) Leader-member exchange partially mediates the relationship between transformational, contingent reward, management-by-exception, laissez-faire leaderships and followers' effectiveness, extra effort, satisfaction and organizational commitment.
\end{abstract}

Keywords leadership effectiveness, transformational leadership, contingent reward leadership, management-by-exception leadership, leader-member exchange

摘要 整合领导者行为和领导下属交换两种视角, 运用中国医药企业的 615 个样本检 验了领导行为、领导下属交换对领导有效性的影响, 发现: (1) 变革型领导有助于员 工绩效、满意度、额外努力和组织承诺的增加; 权变性奖励有助于员工绩效的增加; 例外管理导致员工满意度的降低; 放任型领导导致员工绩效和满意度的降低。

Translated and revised from Guanli shijie 管理世界(Management World), 2006, (9): 87-93

Jean LEE $(\bowtie)$

China Europe International Business School, Shanghai 201206, China

E-mail: Jeanlee@ceibs.edu

WEI Feng

China Europe International Business School, Shanghai 201206, China

E-mail: wfrank@ceibs.edu 
变革型领导既通过领导下属交换的提升引起员工绩效、满意度和组织承诺的增加, 又直接引起额外努力的增加; 权变性奖励（例外管理、放任性领导）完全通过领导 下属交换的提升（降低）引起员工绩效、满意度和组织承诺的增加（降低）。

关键词 领导有效性, 变革型领导, 权变性奖励, 例外管理, 领导下属交换

\section{Introduction}

Leadership in complex organizations is characterized by the parallel development of two different perspectives (Howell and Hall-Merenda, 1999). One viewpoint is leader-focused, which concentrates on the traits and behaviors of leaders, and these behaviors are directly linked to individual, group or organizational outcomes. This viewpoint is exemplified by theories of transformational leadership (e.g., Bass, 1985; Bass and Avolio, 1990). The second perspective focuses on the explicit one-to-one relationships that develop between a leader and a follower. This stream of research proposes a link between follower's performance and the quality and level of mutual trust, respect, and influence within individual leader-follower relationships (Howell and Hall-Merenda 1999). This approach is best exemplified by leader-member-exchange (LMX) theory (Graen and Scandura, 1987; Graen and Uhl-Bien, 1995). A comprehensive literature review shows that few studies have integrated the two perspectives.

As indicated by Howell and Hall-Merenda (1999), leader-focused research often directly links leader behaviors to organizational outcomes (often related to followers), implicitly assuming a relationship of some sort between leader's and followers' behaviors. However, such an approach often fails to answer how, and why certain behaviors work. Research on leader-follower relationships, on the other hand, pays only marginal attention to what leaders do to develop the relationship. Therefore, linking the two perspectives, emphasizing both how leaders behave in order to elicit different levels of follower performance and what leaders do to encourage distinct relationships with each follower is potentially important. First of all, it will facilitate the understanding of the "black box" between observed leader behavior and measured follower outcomes; Secondly, it will facilitate the understanding of leadership in Chinese cultural context.

The current study aims to integrate the two perspectives and link them to leadership effectiveness. While borrowing Bass and Avolio's (1994) leadership framework to encompass the full range of leadership behaviors, using LMX as a mediating variable, the research question is framed as: "How does leadership impact on followers' effectiveness, satisfaction, extra effort and organizational 
commitment, using LMX as the mediating function?

\section{Theories and hypotheses}

After researching on leadership for more than a half century, Hunt (1999) concluded that the leadership field relapsed into the doom and gloom period in the 1970s and early 1980s. A crucial contribution of transformational/charismatic leadership, since the 1980s, has been its rejuvenation of the leadership field. This rejuvenation came about because of the paradigm shift that has attracted numerous new scholars and moved the field out of its doldrums. A search of keywords in materials published from 1990 to 2003 in the PsycINFO database revealed that there have been more studies on transformational or charismatic leadership than on all other popular theories of leadership (e.g., least preferred coworker theory, path-goal theory, normative decision theory, substitutes for leadership) combined (Judge and Piccolo, 2004).

\subsection{Transformational and transactional leadership}

In the past two decades, transformational leadership theory has captured much of the research attention (Judge and Bono, 2000). The concept of transformational leadership can be traced back to Burns's (1978) qualitative classification of transactional and transformational political leaders, although it was the conceptual work by House (1977) and Bass (1981) that brought the concept of transformational leadership to the forefront of leadership research. While Burns' (1978) conceptualization differentiated transforming leadership from transactional leadership and defined them as two ends of a spectrum, Bass (1985) conceptualized them as separate and thus a leader could be both transactional and transformational. Transactional leadership is often depicted as contingent reinforcement; leader-subordinate relationships are based on a series of exchanges or bargains between the leader and the subordinate (Howell and Avolio, 1993). Transformational leaders, however, raise above the exchange relationships typical of transactional leadership by developing, intellectually stimulating, and inspiring subordinates to transcend their own self-interests for a higher collective purpose, mission, or vision (Howell and Avolio, 1993).

In 1991, Bass and Avolio proposed the Full Range Leadership model (FRL model) which has been adopted frequently by recent leadership studies. There are four distinct components that characterize transformational leadership, commonly known as the "Four I's"-Individualized Consideration, Intellectual Stimulation, Inspirational Motivation, and Idealized Influence (Charisma) (Avolio, Waldman and Yammarino, 1991). 
Transactional leadership is a style where the individual gains compliance from followers through either explicit or implicit "contractual" relationships. The leader has expectations and may exchange promises of reward or disciplinary threats for the desired effort, performance level or outcome (Bass and Avolio 1999). In his conceptualization, Bass (1985) also differentiated two types of transactional leadership - contingent reward and management-by-exception (active and passive) - according to the leader's level of engagement with followers and activity level.

Non-leadership is a style where the leader avoids taking any initiative, does not emphasize results and refrains from intervening. Inactive or laissez-faire leadership is the "negation" of leadership (Bass and Avolio 1997); also, it has been repeatedly identified as the most ineffective and dissatisfying form of leadership (Bass and Avolio, 1990).

\subsection{Leadership effectiveness}

According to Bass (1985), transformational and transactional leadership have different effects on followers. Bass (1985) asserted that transformational leadership would result in followers performing beyond expected levels of performance as a consequence of the leader's influence. Specifically, followers' level of extra effort may be due, in part, to their commitment to the leader, their intrinsic work motivation, their level of development, or the sense of purpose or mission that drives them to excel beyond the standard limits. By appealing to the self-interests of followers as well as their shared values, transformational leaders can help their followers collectively maximize performance (Howell and Avolio, 1993). Transformational leadership has been shown to have a direct, positive relationship with performance and satisfaction (See meta-analyses by Gasper, 1992; Lowe, Kroeck, and Sivasubramaniam, 1996).

Transactional leadership based on contingent reward focuses on establishing clear exchanges with their followers (Bass, 1985) and is postulated to result in followers achieving the negotiated level of performance (Howell and Avolio, 1993). In this regard, both the leader and follower reach an agreement concerning what the follower will receive for achieving the negotiated level of performance. Rewards are then provided consistent with satisfactory completion of the agreement. As long as the leader and follower find the exchange mutually rewarding, the relationship is likely to continue and expected performance will be achieved. Unlike transformational leaders, they also tend to exhibit a convergent (coming to the single best answer) rather than a divergent (coming up with creative and new observations) style of thinking. Previous research has shown that leadership behavior based on contingent reward can positively affect followers' satisfaction and performance (Podsakoff and Schriesheim, 1985; 
Podsakoft; Todor, and Skov, 1982; Howell and Avolio, 1993; Lowe, Kroeck, and Sivasubramaniam, 1996).

Conversely, contingent reprimand or disapproval, as exemplified by managing by exception, generally has a negative impact on satisfaction and performance, particularly if the leader passively waits for problems to arise before setting standards or taking any necessary action (Bass and Yamrnarino, 1991; Waldman, Atwater and Bass, 1992; Yammarino and Bass, 1990; Howell and Avolio, 1993). Yet, it is hard to conceive of an effective leader who would not monitor performance and take corrective action when such action was required. At the very least, contingent negative, or aversive, reinforcement serves to clarify roles for followers and, in that sense, represents an important feature of leadership (Yukl, 1981). Yet, used to extreme, or used in place of more constructive forms of leadership, contingent negative reinforcement is likely to have a negative impact on the satisfaction and performance of followers.

Laissez-faire leaders, who avoid taking a stand with their followers, are viewed as less effective (Bass and Avolio, 1994). Prior research (e.g., Bass, 1985; Howell and Avolio, 1993; Lowe et al., 1996) has linked laissez-faire leadership with poor individual and unit performance.

In sum, we predict in Hypotheses 1, 2, 3 and 4 that transformational and contingent reward leadership will have positive effects on followers, however, management-by-exception and laissez-faire leadership will have negative effects on followers.

H1: Transformational leadership is positively related to followers' effectiveness, extra effort, satisfaction and organizational commitment.

H2: Contingent reward leadership is positively related to followers' effectiveness, extra effort, satisfaction and organizational commitment.

H3: Management-by-exception leadership is negatively related to followers' effectiveness, extra effort, satisfaction and organizational commitment.

H4: Laissez-faire leadership is negatively related to followers' effectiveness, extra effort, satisfaction and organizational commitment.

\subsection{The mediating effect of leader-member exchange}

Leader-Member Exchange (LMX) theory suggests that leaders do not use the same style in dealing with all subordinates, but rather develop a different type of relationship or exchange with each subordinate (Dansereau, Graen and Haga 1975; Graen and Scandura 1987). Leaders convey role expectations to their followers and provide tangible and intangible rewards to followers to fulfill their expectations. Likewise, followers hold role expectations of their leaders, with respect to how they are to be treated and the rewards they are to receive for meeting leader expectations (Wang, Law, Hackett, Wang and Chen, 2005). These 
relationships range from those which are based on exchanges directly specified by the employment contract (i.e., low LMX or "out-group") to those which include the exchange of both material and nonmaterial goods that extend beyond what is required by the employment contract, like mutual trust, respect, liking and reciprocal influence (i.e., high LMX or "in-group") (Dansereau, et al. 1975; Liden and Maslyn, 1998; Greguras and Ford, 2006).

As LMX relationships are based on exchanges, subordinates who are better supported by, and integrated into, the organizations are likely to reciprocate by being more satisfied with (Esienberger, Cummings, Armeli, and Lynch, 1997), involved with (O'Driscoll \& Randall, 1999), and committed to their jobs (Randall, Cropanzano, Bormann, and Birjulin, 1999). Subordinates in high quality LMX relationships are also expected to engage in more task-oriented (Duarte, Goodson and Klich, 1993) and discretionary behaviors (LePine, Erez, and Johnson, 2002) than those in lower quality LMX relationships. Past research supports many of these theoretical links by observing that subordinate measures of LMX relate to satisfaction with supervisor (Liden and Maslyn, 1998; Schriesheim and Gradiner, 1992), organizational commitment (Duchon, Green and Taber, 1986; Green, Anderson and Shivers, 1996; Kinicki and Vecchio, 1994), in-role performance (Duarte et al., 1993) and OCBs (LePine et al., 2002; Wang et al, 2005).

Graen (1976) noted the importance of leadership behaviors in the role-making process of LMX. It is through establishing high-quality relationships that leaders, by example and by treatment, convince followers that an organization deserves their dedication. Just as Howell and Hall-Merenda (1999) suggested, leader-focused research often directly links leader behaviors to organizational outcomes (often related to followers), implicitly assuming a relationship of some sort between leader and follower, which facilitates leader behavior to affect follower's response in a certain pattern. Avolio, Sosik, Jung and Berson (2003) also noted that, "to make sense of each follower's future requires the leader to develop a relationship, whereby followers come to identify with the leader's vision". Empirically, Wang, Law, Hackett, Wang and Chen (2005) found that it is the quality of the leader-follower relationship through which transformational leadership behaviors influence follower's performance and OCB. Thus, it is suggested that LMX may be an important factor facilitating the leadership effect on followers' attitudes and behaviors. Thus, we propose the following hypotheses:

H5: LMX mediates the relationship between transformational leadership and followers' effectiveness, extra effort, satisfaction and organizational commitment.

H6: LMX mediates the relationship between contingent reward leadership and followers' effectiveness, extra effort, satisfaction and organizational 
commitment.

H7: LMX mediates the relationship between management-by-exception leadership and followers' effectiveness, extra effort, satisfaction and organizational commitment.

H8: LMX mediates the relationship between laissez-faire leadership and followers' effectiveness, extra effort, satisfaction and organizational commitment.

\section{Methods}

\subsection{Sample}

The sample of the pilot study consisted of 615 employees in five pharmaceutical companies located in Shanghai, Hubei Province, Zhejiang Province, Shandong Province and Liaoning Province in China. These companies were large organizations with employee size around 1000-2000 and had several branches or subordinate companies. 100-150 questionnaires were sent to each company. Of the 720 subordinate questionnaires distributed, a total of 698 completed questionnaires were sent back. As a gauge, questionnaires with more than $10 \%$ missing data were eliminated. The final sample was comprised of 615 respondents. Among them, 59\% were males, 48\% were between age 20 to 30, 39\% were between age 31 to $40,69 \%$ had college to bachelor degrees.

\subsection{Measures}

The questionnaire contained the following three parts and demographic information.

Leadership and effectiveness. Leadership was measured with Bass and Avolio's (1995) Multifactor Leadership Questionnaire (MLQ) Form 5X which comprised of forty-five items measuring the five leadership dimensions that Bass and Avolio $(1993,1997)$ identified in the FRL model and three outcome indicators for leadership-satisfaction, extra effort and effectiveness. Sample items in the dimensions are: my supervisor treats me as an individual rather than just a member of the group (transformational leadership), my supervisor points out what I will receive if I do what is required (contingent reward leadership), my supervisor focuses attention on irregularities, mistakes, exceptions and deviations from what is expected of me (management-by-exception active leadership), problems have to be chronic before my superior will take action (management-by-exception passive leadership), my supervisor avoids making decisions (laissez-faire leadership), his/her performance meet organizational 
demand(effectiveness), my performance exceeds expectations under his/her leadership (extra effort), the leadership of my supervisor is satisfying (satisfaction). Respondents were asked to rate these items on a 5-point scale ranging from 0 (not at all) to 4 (frequently, if not always). In the current study, the coefficient alphas of transformational, contingent reward, management-by-exception, laissez-faire leadership, effectiveness, extra effort, and satisfaction were $0.91,0.59,0.70,0.74,0.75,0.63$ and 0.88 respectively.

Leader-follower relationship. The subordinates were asked to assess the quality of LMX by using the seven-point LMX-7 scale developed by Graen and Uhl-Bien (1995) and validated by Schaubroeck and Lam (2002) in the Chinese context. The scale consists of seven items that characterize the overall effectiveness of the relationship between supervisor and subordinate. Sample items are: "How would you characterize your working relationship with your leader?" and "How well does your leader understand your job problem and needs?" with a response scale from 1-not at all to 7-completely. In the current study, the coefficient alpha was 0.90 .

Organizational commitment. Meyer and Allen's (1997) instrument for the multidimensional organizational commitment was adopted. The scale consists of 23 items that characterize the employee's affective, continuance, and normative commitment to their organization. Sample items are: "I really feel as if this organization's problems are my own" and "I would be very happy to spend the rest of my career with this organization". Respondents were asked to rate these items on a 7-point scale ranging from 1-not at all to 7-completely. In the current study, the coefficient alpha was 0.75 .

The original questionnaire was in English and was translated from English into Chinese by a bilingual speaker of Chinese and English. The Chinese questionnaire was then given to another bilingual speaker to back-translate into English. In cases where the back-translation was not equivalent to the original version, the process of translation was repeated.

\section{Results}

Table 1 presents the means, standard deviations, reliability coefficients, and inter-correlations of all the studied variables. In general, transformational and contingent reward leadership correlated positively with followers' outcomes; management-by-exception and laissez-faire leadership correlated negatively with the variables. The results support hypotheses 1 to 4 . 


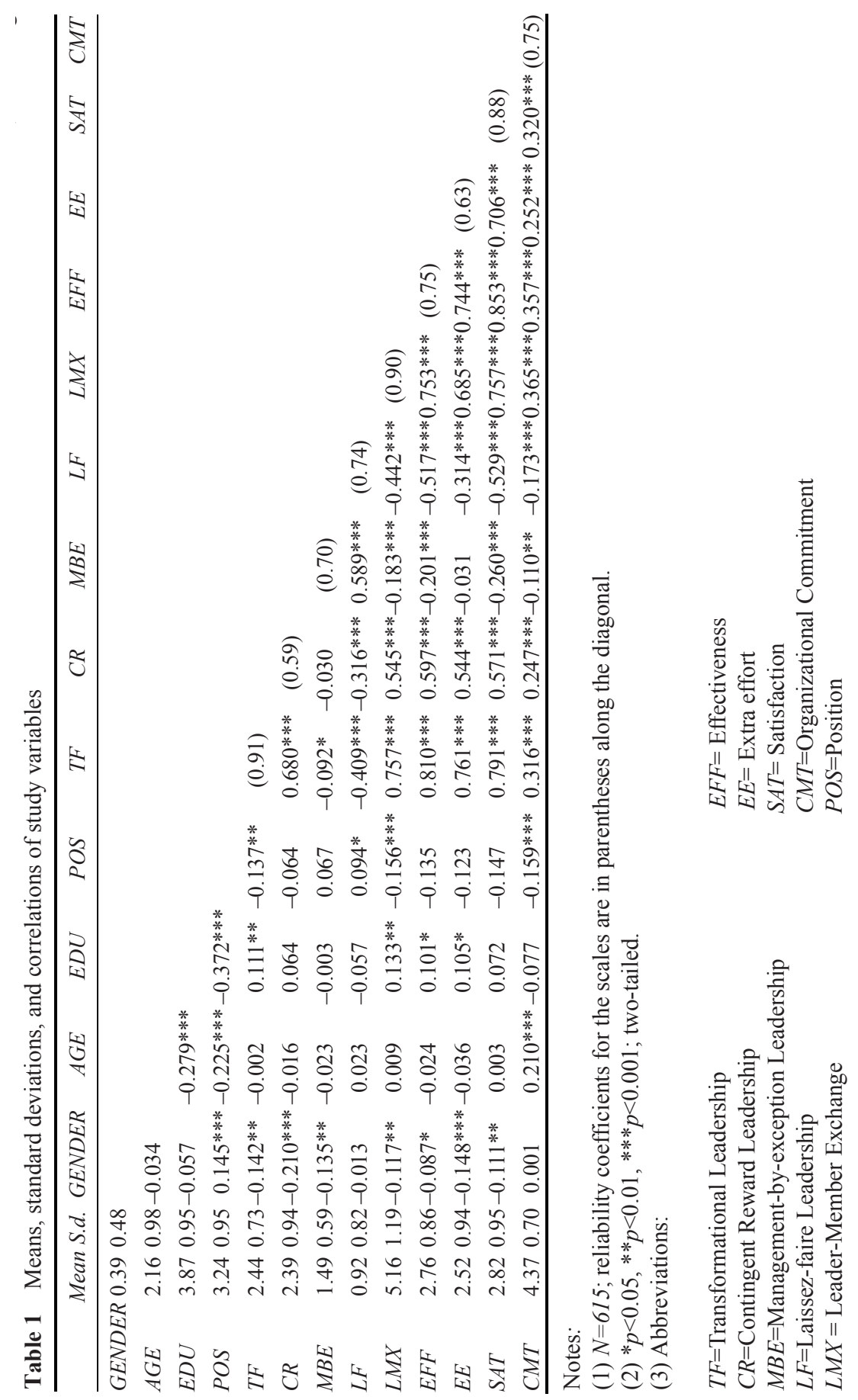


Hierarchical regression analysis was conducted to test the hypotheses. To test hypotheses 1-4, after entering all of the control variables in Step 1 (see Table 2 Model-2), we regressed the independent variables (the four dimensions of leadership) on the independent variable (follower's outcome) in Step 2. Results indicated that, after controlling for the effects of gender, age, education level, and position, transformational leadership was positively related to follower's effectiveness, extra effort, satisfaction and organizational commitment significantly, which supported hypothesis 1; contingent reward leadership was positively related to follower's effectiveness significantly, but not to extra effort, satisfaction and organizational commitment, which partially supported hypothesis 2; management-by-exception leadership was negatively related to follower's satisfaction significantly, but not to effectiveness, extra effort, and organizational commitment, which partially supported hypothesis 3 ; laissez-faire leadership was negatively related to follower's effectiveness and satisfaction significantly, but not to extra effort and organizational commitment, which partially supported hypothesis 4 .

To test the mediating effect, we followed Baron and Kenny's (1986) process. They proposed a three-step procedure to test a mediation model. Firstly, the independent variables should be significantly related to the mediating variables; secondly, the independent variables should be related to the dependent variables; and finally, the mediating variables should be related to the dependent variables with the independent variables controlled for in the model. If the beta weights of the independent variables are still significant in the last step, partial mediation is present. If the beta weights of the independent variables are not significant, full mediation is present. As shown in Table 2 (Model-1), after entering all of the control variables in Step 1, we regressed the independent variables (the four dimensions of leadership) on LMX in Step 2. Results indicated that the four dimensions of leadership were all related significantly to LMX, which fulfilled the first requirement for mediation. In Table 2 (Model-3), after entering all of the control variables in Step 1, we regressed the mediator (LMX) on the dependent variables. Results indicated that LMX was related significantly to all the four follower's outcomes, which fulfilled the third requirement for mediation. Since hypotheses 1 to 4 had been supported, we concluded that the second requirement for mediation was fulfilled.

As shown in Table 2 (Model-4), after entering the control variables in step 1 and the independent variables in step 2, we regressed the mediator (LMX) on the dependent variables. The results indicated that partial mediations of LMX were present in the four dimensions of leadership and follower's effectiveness, extra effort, satisfaction and organizational commitment, which supported hypotheses 5 to 8 . 


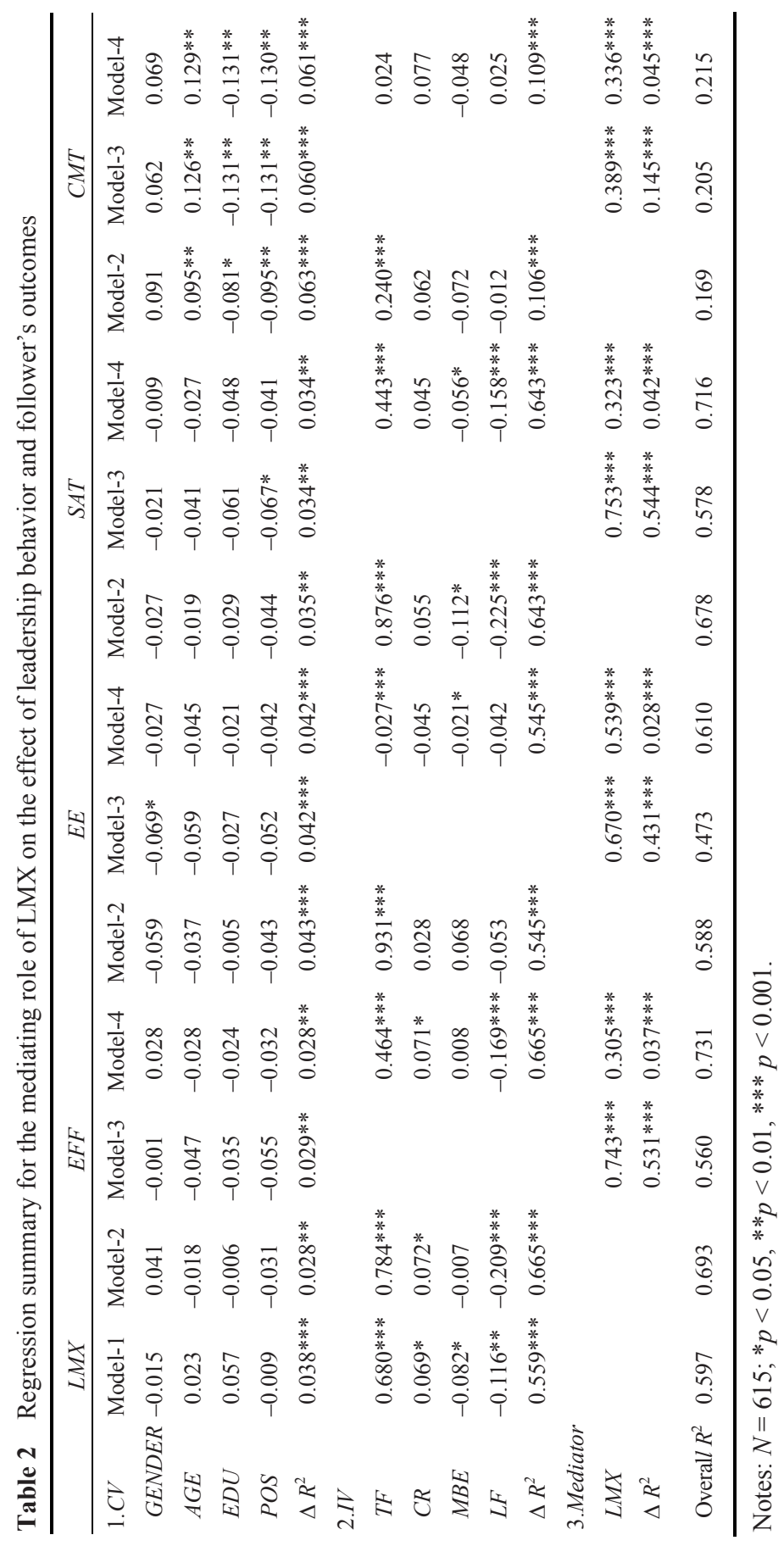




\section{Discussion}

The current research findings demonstrated that the more active and constructive a leader is, which is represented by higher frequency of transformational and contingent reward styles, the higher level of LMX he/she is possible to create with followers. This is fully consistent with former research done by Bass and Avolio's (1995) in-scale test of transformational and contingent reward leaders' effectiveness. In contrast, the more passive corrective style a leader exhibits, which is represented by higher frequency of management-by-exception and laissez-faire leadership, the lower level of LMX he/she will create with followers, and the results also suggested that followers' effectiveness, extra effort, satisfaction and organizational commitment tends to be lower. The current study also demonstrated that the partially mediated model represented the largest possibility to integrate the two perspectives.

\subsection{Active constructive and passive corrective leadership}

It is evident to view the results as being generally consistent with Bass and Avolio's five-factor leadership model, in both the way leadership styles are observed and their relative desirability and effectiveness. Yet the findings revealed that the acquired data in China on the leadership part was best represented by a two-factor model, which included two larger dimensions, namely ACL (Active Constructive Leadership) and PCL (Passive Corrective Leadership). The former dimension encompassed the original transformational leadership items and the contingent reward leadership items; while the latter included the management-by-exception leadership and laissez-faire leadership items. This phenomenon corresponded with the recent claim that the MLQ scale might not account for the five-factor structure when empirically examined (Bass and Avolio, 1999), instead, it exhibits a higher-order leadership model.

Specifically, items depicting contingent reward leadership loaded into the first factor and correlated highly with transformational leadership, suggesting that respondents in this study were not quite clear about the distinction between the two leadership styles. This finding is also consistent with the argument that transformational leadership is "the extension of transactional leadership, with greater leader intensity and follower arousal", and a considerable number of studies have empirically claimed that contingent reward tends to load into the same factor as transformational leadership (Waldman, Bass and Einstein, 1987). In contrast, management-by-exception-passive leadership and laissez-faire leadership loaded into one general factor, the commonalities among the two may 
be that they are corrective and passive, thus generating negative feedback and reinforcement.

Although the two-factor solution provides a useful research solution, distinguishing between different components of transformational and transactional leadership may remain useful for evaluating, training and self-development purposes.

\subsection{The mediating effects of LMX}

Results of the SEM model showed that a partially mediated model fitted the data, with LMX as the mediator between leadership and follower's effectiveness, extra effort, satisfaction and organizational commitment. This indicated that leadership has direct impact on followers' outcomes, and at the same time this relationship is mediated by LMX.

Not uniquely, similar phenomenon was found in Howell and Hall-Merenda's (1999) study. They found a failure when they tried LMX as a mediator between transformational leadership and organizational performance because of insignificant relationship. One possible explanation was that despite the demonstrated discriminant validity between the LMX and ACL constructs, the significant correlation between them may have attenuated the relationship between ACL and follower's outcome. An alternative explanation could be that some moderators need to be added in the analysis if transformational leadership and LMX are differentially related to follower's outcome.

\subsection{Contributions and limitations}

This study has significant implications for management. As transformational and contingent reward leadership practice highly effective and efficient styles, keep inspiring and motivating followers, challenging and coaching them, develop high quality of leader-follower relationship, followers will show more respect, make more contribution and display higher level of organizational commitment, thus greatly enhance organizational effectiveness. However, neither the highly recommended leadership styles nor good quality of leader-follower relationships is something that is fostered overnight. They are the result of long periods' cultivation. Practitioners' awareness is strongly called for that leadership is a state-of-art, which requires not only leaders' self-cultivation in their personal styles but also appropriate and intelligent conduct when facing with followers.

Our findings also provide insights into how high-quality leader-member exchange relationships can be developed. The LMX literature focuses strongly on the outcomes of high-quality leader-member exchange, giving less attention to 
how leaders can build high-quality exchange relationships with their followers. Our findings suggest that transformational and contingent reward leadership behaviors are instrumental to developing high-quality LMX relationships. If leadership programs are aimed at developing the quality of transformational and contingent reward leadership behaviors, leader-follower dyadic relationships and leadership effectiveness can be enhanced too.

One limitation of the present study lies in the cross-sectional nature of the data. Since data on leadership, LMX and organizational commitment were collected at the same point, the verification of the causal nature of the relationships was discounted. This study might be vulnerable to the possibility of opposite or bi-directional causal explanations. Future study is needed using longitudinal approach, carefully using newly-established reporting relationships at the beginning and tracking the relationship for a certain period to watch the outcome variables. Another limitation of this study is that leadership and LMX were both measured from followers' perspectives only. Gerstner and Day (1997) suggested future research measuring LMX from both leader and follower viewpoints and examining the leader-follower agreement as a relevant independent or dependent variable.

\section{References}

Avolio B J, Sosik J J, Jung D I, Berson Y(2003). Leadership models, methods and applications: Small steps and giant leaps. In: W C Borman, R J Klimoski, D J Ilgen, I B Weiner(Eds.), Handbook of Psychology, Vol. 12: Industrial and Organizational Psychology, 277-307. New York: John Wiley \& Sons

Avolio B J, Waldman D A, Yammarino F J(1991). Leading in the 1990s: The four is of transformational leadership. Journal of European Industrial Training, 14(4): 9-16

Baron R M, Kenny D A (1986). The moderator-mediator variable distinction in social psychological research: Conceptual, strategic, and statistical considerations. Journal of Personality and Social Psychology, 51(6): 1173-1182

Bass B M (1981). Stogdill's Handbook of Leadership: A Survey of Theory and Research. New York: Free Press

Bass B M (1985). Leadership and Performance Beyond Expectations. New York: Free Press

Bass B M, Avolio B J(1990). Developing transformational leadership: 1992 and beyond. Journal of European Industrial Training, 14(5): 21-27

Bass B M, Avolio B J (1993). Transformational leadership: A response to critiques. In: M M Chemers \& R Ayman (Eds.), Leadership Theory and Research: Perspectives and Directions, 49-80. San Diego: Academic Press

Bass B M, Avolio B J (1994). Full Range of Leadership Development: Improving Organisational Effectiveness through Transformational Leadership. Thousand Oaks, CA: Sage Publications

Bass B M, Avolio B J (1995). MLQ Multifactor Leadership Questionnaire Sampler Set: 
Technical Report, Leader Form, and Scoring Key for MLQ Form 5x-Short. Redwood City, CA: Mind Garden

Bass B M, Avolio B J (1997). Full range of Leadership: Manual for the Multifactor Leadership Questionnaire. Palto Alto, CA: Mind Garden

Bass B M, Avolio B J (1999). Training Full Range Leadership. Redwood, CA: Mind Garden

Bass B M, Yammarino F J (1991). Congruence of self and others' leadership ratings of naval officers for understanding successful performance. Applied Psychology: An International Review, 40: 437-454

Burns J M(1978). Leadership. New York: Harper \& Row

Dansereau F, Graen G, Haga W J (1975). A vertical dyad linkage approach to leadership within formal organizations: A longitudinal investigation of the role-making process. Organizational Behavior and Human Performance, 13: 46-78

Duarte N T, Goodson J R, Klich N R (1993). How do I like thee? Let me appraise the ways. Journal of Organizational Behavior, 14, 239-249

Duchon D, Green S, Taber T (1986). Vertical dyad linkage: A longitudinal assessment of antecedents, measures, and consequences. Journal of Applied Psychology. 71: 56-60

Eisenberger R, Cummings J, Armeli S, Lynch P (1997). Perceived organizational support, discretionary treatment, and job satisfaction. Journal of Applied Psychology, 82: 812-820

Gasper S (1992). Transformational leadership: An integrative review of the literature. Doctoral dissertation, Western Michigan University

Gerstner C, Day D (1997). Meta-analytic review of leader-member exchange theory: Correlates and construct issues. Journal of Applied Psychology, 82(6): 827-844

Graen G B (1976). Role-making processes within complex organizations. In: M D Dunnette (ed.), Handbook of Industrial and Organizational Psychology. Chicago: Rand McNally

Graen G B, Scandura T A (1987). Towards a psychology of dyadic organizing. In: L L Cummings \& B M Staw (Eds.), Research in Organizational Behavior, Vol. 9, 175-208. Greenwich, CT: JAI Press

Graen G B, Uhl-bien M (1995). Development of LMX theory of leadership over 25 years: Applying a multi-level-multi-domain perspective. Leadership Quarterly, (6): 210-247

Green S G, Anderson S E, Shivers S L (1996). Demographic and organizational influences leader-member exchange and related work attitudes. Organizational Behavior and Human Decision Processes, 66: 203-214

Greguras G J, Ford J M (2006). An examination of the multidimensionality of supervisor and subordinate perceptions of leader-member exchange. Journal of Occupational and Organizational Psychology, 79(3): 433-465

House R J (1977). A theory of leadership effectiveness. In: J G Hunt \& L L Larson (Eds.), Leadership: The cutting edge, 189-207. Carbondale: Southern Illinois Press

Howell J M, Avolio B J (1993). Transformational leadership, transactional leadership, locus of control, and support for innovation: Key predictors of consolidated business unit performance. Journal of Applied Psychology, 78: 891-902

Howell J M, Hall-Merenda K E (1999). The ties that bind: The impact of leader-member exchange, transformational and transactional leadership, and distance on predicting follower performance. Journal of Applied Psychology, 84: 680-694

Hunt J G (1999). Transformational/charismatic leadership's transformation of the field: An history essay. Leadership Quarterly, 10(2): 129-144

Judge T A, Bono J E (2000). Five-factor model of personality and transformational leadership. Journal of Applied Psychology, 85: 751-765 
Judge T A, Piccolo R F (2004). Transformational and transactional leadership: A meta-analytic test of their relative validity. Journal of Applied Psychology, 89 (5): 755-768

Kinicki A J, Vecchio R P (1994). Influences on the quality of supervisor-subordinate relations: The role of time-pressure, organizational commitment, and locus of control. Journal of Organizational Behavior, 15: 75-82

LePine J A, Erez A, Johnson D E (2002). The nature and dimensionality of organizational citizenship behavior: A critical review and meta-analysis. Journal of Applied Psychology, 87, $52-65$

Liden R C, \& Maslyn J M (1998). Multidimensionality of leader-member exchange: An empirical assessment through scale development. Journal of Management, 24(1): 43-72

Lowe K B, Kroeck K G, Sivasubramaniam N (1996). Effectiveness of correlates of transformational and transactional leadership: A meta-analytic review of the MLQ literature. Leadership Quarterly, 7(3): 385-425

Meyer J P, Allen N J (1997). Commitment in the Workplace: Theory, Research and Application. London: Sage

O’Driscoll M P, Randall D M (1999). Perceived organizational support, satisfaction with rewards, and employee job involvement and organizational commitment. Applied Psychology: An International Review, 48: 197-209

Philip M P, Chester A (1985). Field studies of French and Raven's bases of power; Critique, reanalysis, and suggestions for future research. Psychological Bulletin, 97(3): 387-411

Podsakoff P M, Tudor W D, Skov R (1982). Effects of leader contingent reward and noncontingent reward and punishment behaviors on subordinate performance and satisfaction. Academy of Management Journal, 25(4): 810-821

Randall M L, Cropanzano R, Bormann C A, Birjulin A (1999). Organizational politics and organizational support as predictors of work attitudes, job performance, and organizational citizenship behavior. Journal of Organizational Behavior, 20: 159-174

Schaubroeck J, Lam S S K (2002). Dispositional similarity, group homogeneity and organizational advancement in different cultures. Academy of Management Journal. 45(6): $1120-1136$

Schriesheim C, Gardiner G (1992). A comparative test of magnitude estimation and pair-comparison treatment of complete ranks for scaling a small number of equal-interval frecuency response anchors. Educational and Psychological Measurement, 52: 867-877

Waldman D A, Bass B M, Einstein W O (1987). Leadership and outcomes of performance appraisal processes. Journal of Occupational Psychology, 60: 177-186

Waldman D, Atwater L, Bass B (1992). Transformational leadership and innovative performance in an R \& D laboratory. Final Technical Report, Center for Leadership Studies

Yammarino F J, Bass B M (1990). Transformational leadership and multiple levels of analysis. Human Relations, 43: 975-995

Yukl G A (1981). Leadership in Organizations. Englewood Cliffs, NJ: Prentice-Hall 